\title{
The Iron Age looks at Rome for the first time in audiovisuals: fiction, cultural imaginary and historical reality in Barbarians and Britannia
}

\author{
Manuel Gago Mariño ${ }^{1} \&$ Jesús García Sánchez ${ }^{2}$ \\ ${ }^{1}$ Department of Communication Sciences. Universidad de Santiago de Compostela \\ ${ }^{2}$ Archaeological Institute of Mérida, CSIC - Junta de Extremadura
}

\begin{abstract}
Two recent fiction series produced for video-on-demand (VOD) platforms show the conflict between the Roman Empire and indigenous peoples from the perspective of the latter for the first time. Thus, transforming the traditional Roman historical genre into a more diverse and multifocal space. But, in Barbarians and Britannia this new audiovisual optic manages the representation of this historical reality in completely opposite ways.
\end{abstract}

Keywords: Video-on-demand, Roman Archeology, Iron Age archaeology, Identity, Representation

\section{Die Barbaren / Barbarians (Netflix, 2020)}

Netflix's Barbarians taps into the historical productions about the Roman world that from time to time brighten up the lives of those of us who are professionally dedicated to learning and unravelling the history of ancient Rome. The fascination of cinema with Ancient history is a well known aspect of the film industry. Hollywood and other national producers (chiefly Italy and Spain) found inspiration in Biblical texts, and in Greek / Roman comedy and drama to create the so-called peplum genre. This genre was used to portray many different topics in idealized Greek, Mesopotamian or Roman scenarios.

Peplum is a Latin word which describe a dress type, and was popularize to describe the cinema genre ambience in the Graeco-Roman antiquity, this particular genre was a trend during the second half of the twentieth century despite its origins could be traced to first decades of the twentieth century (Siclier 1962; Gonzales 1990). In the following paragraphs, we will refer to peplum to characterize movies inspired in Antiquity, regardless of the overall topic of such movies.

Barbarians is not only a historical drama built on a relevant event of the past - the battle of Teutoburg (CE 9); it also presents many elements to reflect on. Above all, we may find it interesting from an historical point of view, as it seems evident that there is a clear aim to represent historic reality as transmitted by Latin sources and archaeological research. For 
example, Barbarians joins the league of television series about antiquity that propose an alternative history to the overwhelming Roman narrative that originally dominated the audiovisual world, from the classic peplum to its peak with TV series such as Rome (BBC, HBO, RAI, 2005), through I, Claudius (BBC, 1976), or Imperium (Antena 3, 2012). In series such as Spartacus (STARZ, 2010), Britannia (Sky and Amazon Prime Video, 2018), or Hispania, la leyenda (Antena 3, 2010), the emphasis is placed on the role of the many and varied indigenous peoples in the face of the military and political problems caused by Rome's expansionism. Although set on Italian soil, in the case of Spartacus this is represented through the enslaved gladiators or in flashbacks to Spartacus's Thracian origin; even Life of Brian (Monty Python, 1979) offers this alternative account, from the Judaic perspective, to the Roman control of Judea. These views of the Roman world tie in with the post-colonial, or decolonising, approach to narrative history that is re-shaping the foundations of classical archaeology in academia, and in which we can see how perspectives privileging "Romanisation", the widespread adoption of Roman culture by subject peoples, are in decline in favour of views where the character, resistance, and resilience of conquered peoples regain their role in the historical process.

The question is why is this paradigm shift also taking place in the audiovisual field? It is not clear whether a deliberate post-colonial reflection has been present in the making of the series, or whether the tendency to emphasise alternative and opposing visions to the expansion of the Roman Empire is rooted in a vindication of nation-states in the crisis of the global economy. That is, in the reassertion of values of nationhood, organisation, and primordial independence, in the face of the integrated and homogenising global world represented by Rome's imperial policy. Nowadays new visions on hybridization, religion, globalization and resilience teach us how Rome used the heterogeneity of its territory in its own profit.

In Barbarians the dialectic of free nation versus imperialist power is reflected in the use of the Latin language by Romans addressing the Cherusci, which leads us to believe that the modern German language spoken by the tribes is presented as if it were indeed an original Germanic language. This is despite the incommensurability of today's German with the Germanic languages spoken 2000 years ago (Houten 2021).

What would Slavoj Zizek, as a critic of audiovisual culture, say about this transformation of historical "reality" into a "fiction" for mass-media communication? We could imagine that he would argue about the survival of national ideology in the twenty-first century and its reproduction through consumer products and culture. In a similar way to his famous national toilet (Zizek 1997), national ideology seeks its self-representation in distant pasts through official and unofficial (audiovisual) media in which archaeology plays an important role (García Sánchez 2009).

There are other important elements in Barbarians, such as lessons in history and archaeology that have been transmitted from archaeological literature to the small screen; all without losing a strong overlap with the historical ethnography transmitted by both Latin sources, and archaeological research. This aspect constructs what we could call audiovisual scientism in which the aim of Barbarians is a strong aim to accommodate historic reality in the narration is confronted with what we will term "the audiovisual ethnography" represented by the Britannia series (see below). 
Several aspects of the series deserve to be highlighted, appreciated and perhaps discussed. Among them are some interesting concepts such as the social organisation of the Germanic peoples, their settlement pattern in the absence of cities described by Julius Caesar in the Gallic War, their weapons or ways of fighting (totally naked) described by Tacitus and Veleius Paterculus, their material culture perhaps, or even their tribal political organisation organised around the thing or ding, and the heterogeneity of the peoples and their different ways of obtaining alliances with each other or with third parties (including Rome!). In the series, there are mentions of Cherusci, Brupteri, Cati or Marsi (episode 1), whose identity is always defined by those of the opponent (episode 1), however from within the society it is recognised that certain traits, such as tradition or type of burial, characterise their culture, and identify the individuals who practice it with that culture.i.e. Arminius buries Folkwin's relatives using customary rituals which makes him part of the same ethinc group, he realized this when confronted with fact by Thusnelda.. Bringing this same debate to our own history, we recognise how Roman historiography understood the geographical reality obviating the nuances that gave it meaning. For the Romans, the Germanic tribes were just barbarians, as well as in the Iberian Peninsula, other ethnic groups as the Arevacs, Titii, Beli, Lusoni, etc, were termed with the generic definition of Celtiberians. This is a term never used before the conquest, but which became an ethnonym only through Roman usage (Beltrán Lloris 2004).

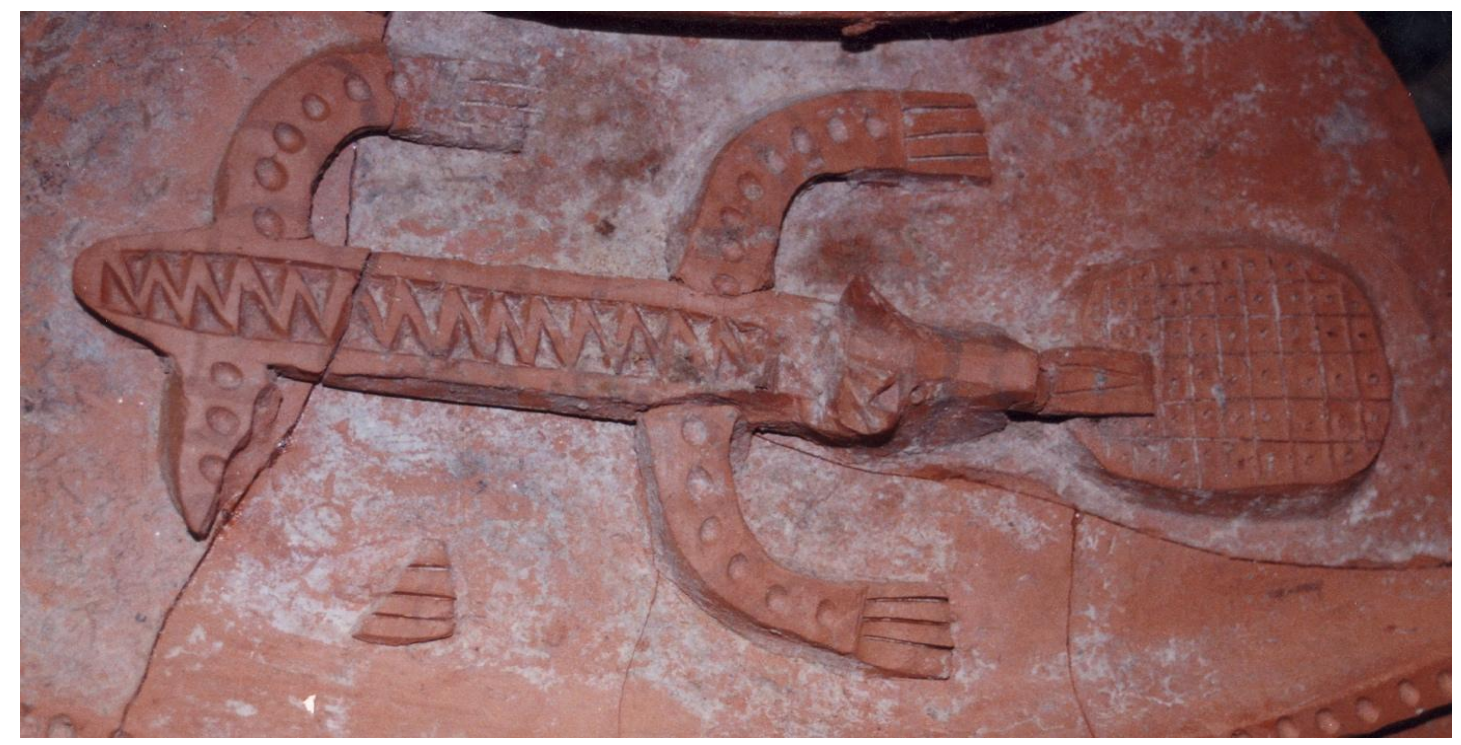

Figure 1. Wolf eating a cake (Roa de Duero, Burgos) (Abarquero-Aratikos).

One interesting point which may help to confront Barbarians with archaeological research is how ethnical and identitarian divisions are portrayed. Meanwhile the heterogeneous composition of society and the diversity (material culture, language, settlement pattern, types of burial or even in the diversity of political and social organisations) is correctly address by Barbarian, I fear that some parts of the academia blur this heterogeneity in favour of a diffuse celtism on continental scale.

The series exploits cosmogony centred on the wolf in a suggestive way (episode 3). It contrasts the indigenous society, fearful of the "wolf that will devour the moon, the wolf will devour the sun", with Rome identified with Luperca, the she-wolf that suckled 
Romulus and Remus. As presented by Barbarians this might be seen as tautology (Rome indeed will end the Germanic world, we know it) However, it reminds us of a real Iron Age cosmogony. The wolf eating the world is also well represented among the Vacceans of the Duero river valley. Specifically, the large vessel from Rauda (Roa, Burgos) depicts a wolf seen from above licking/ eating a circular cake (Abarquero 2006) (Fig. 1).

From the point of view of the Romans who appear in the Barbarians series, we can also obtain interesting elements for reflection. One of them, perhaps because of its historical relevance, is the integration of Germanic auxiliaries into the Roman troops; a fact that began with the collaboration of the Germans in Julius Caesar's victory over Vercingetorix in Gaul, and the subsequent campaigns of Tiberius. From then on, the Romans promoted the Germanic elites through their integration into Gaul, rewarded with Roman citizenship in the ranks of the equites, something which the Germans eventually saw as insufficient to their demands.

Finally, an aristocratic or military society, such as the Germanic one, which reproduced its existence through conflict, failed to assimilate the growing pressure of the Roman officialdom represented here by Varus; although in conclusion, it did take on much of the Roman way of life, and as Varus' Greek slave translates to Segestes, "Rome will teach you to fill the granaries", see for example Nico Roymans' (1996) "From the sword to the plough".

A recommendable series, where the historical narrative is intermingled with great archaeological and ethnographic documentation; and where there is no lack of elements of reflection on nation states and their historicist foundations in an already mature $21 \mathrm{st}$ century.

\section{Britannia (Sky and Amazon Prime Video, 2018)}

The British Isles has a strong tradition of recreating Roman-era historical audio-visuals. Interestingly, it is precisely these classical historical productions that have produced notable milestones in global audiovisual storytelling. I, Claudius (BBC, 1976) can be considered one of the best audiovisual products of this type due to the psychological complexity of the characters, the celebrated Rome (BBC, HBO, RAI, 2005), inaugurated in the wake of The Sopranos (HBO, 1999), represents a new concept of television series to which the great current video-on-demand productions are heirs, with a concern for historical accuracy and setting combined with complex dramatic structures that played out over entire seasons. 


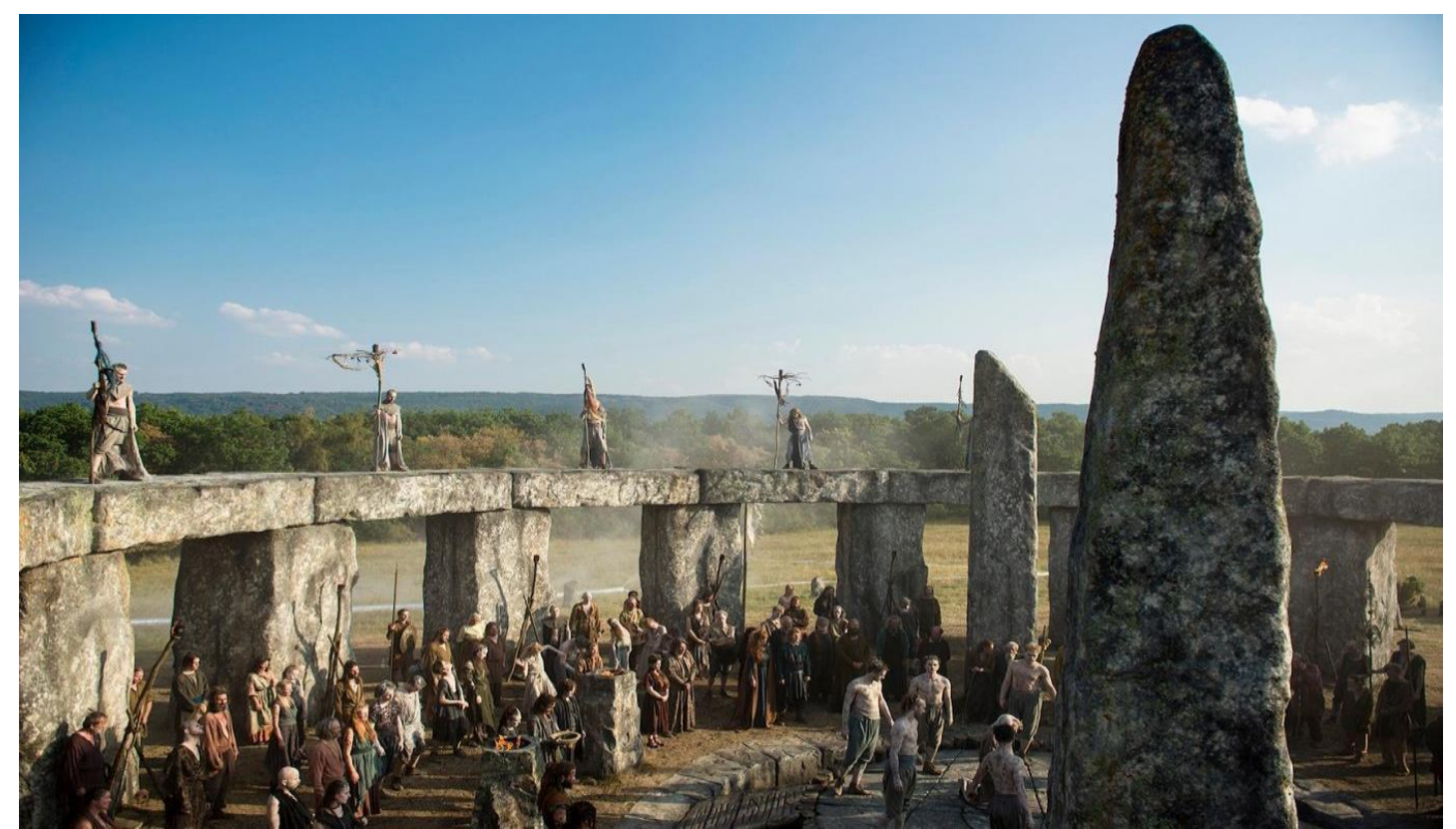

Figure 2. In Britannia, aggregation spaces, power legitimation and cult in a crómlech resembling Stonehenge.

The UK has also produced important films that redefined the concept of the "peplum" film genre, such as Gladiator (Ridley Scott, 2000), which alternated the traditional perverse vision of the emperors with a new figure of the melancholic and unshakeable hero, faithful and independent in his values; moreover, Gladiator offers one of the best filmed battles on the Germanic limes. And, symptomatically, ten years later there was a new twist in the genre, represented by the films Centurion (Neil Marshall, 2010) and The Eagle (Kevin Macdonald, 2011), which in both cases cross the boundary that Gladiator had begun to draw in the cinematic imagination. In these two cases, the Roman legionaries stationed on the northern border of the Roman province of Britannia are introduced into a Caledonia constructed in the image and likeness of the clichés of classical texts. A barbaric space that, at the same time, reveals the narrative gaps in the classical sources about the Caledonians. To construct an audiovisual ethnography of the indigenous people of northern Britain, the producers drew on a symptomatic reference: the numerous examples of cinematic recreation of the indigenous peoples of eastern Canada and New England and their relations with settlers and conquerors. This is carried over into the props, makeup and even certain types of scenes of movement through the wilderness are recognisable. These Iron Age Britons in the audiovisuals of the early 2010s are very reminiscent of peoples who are much represented in American cinema, such as the Iroquois. It is at this point that we become aware of what we are actually seeing: the fusion of peplum and western, and the construction of a barbarian - perhaps still very dark - who stands on the border of cruelty, magic and sometimes humanity. In differentiating the Romans from the Caledonians, the team of Centurion and The Eagle do not stray far from the Roman historians' own premises for connoting barbarians. Yet the production's point of view begins to show a new proximity to the others who live beyond the walls of civilization.

The production of Britannia (Sky and Amazon Prime Video, 2018), which is a new twist on the historical audiovisual in Roman times, is therefore very interesting. Like Barbarians, the perspective is new: the story is told from the indigenous, during the process of the 
conquest of the island in the time of Emperor Claudius. The Roman becomes a powerful counterpart who, by his actions, provokes, triggers and transforms the conflicts of the British protagonists. However, unlike Barbarians, Britannia has no pretensions to history, and to construct the British Iron Age it starts from another, perhaps surprising, place: the cultural imaginary created about the Iron Age since the nineteenth century, linked to the Celtic rising. It is possible to recognise in some scenes of the series the inspiration of the numerous 19th and early twentieth century engravings depicting druids practising rites in megalithic monuments (Fig. 2), a Stonehenge reconstruction will become one of the main settings of Britannia. The characters appear to have been based on the visual models percolating from the early recreations of Celtic Britons in histories of Britannia from the sixteenth century onwards, such as those of Lucas de Heere (Fig. 3).

While Centurion and The Eagle are clearly linked to the western movies, and this idea of territory as a space in which the real and the unreal, the ancestral and the warlike rigour of the present action converge, in Britannia another British audiovisual tradition is added, the folk horror coined by the actor Mark Gatiss and which perhaps had its most connected exponent with Celtic cultures in The Wicker Man (Robin Hardy, 1973). In this film, Caesar's and Strabo's references to this peculiar form of sacrifice -men trapped and burned inside a timbered giant- among the Gauls converge with the interest in sects that has been emerging in these B-movies since the late 1960s. In Britannia, the Druids will also behave as an opaque and perverse sect, with the capacity to subtract wills and with a certain propensity for the spectacle of human sacrifice. But in Britannia we will see something new in these Roman and indigenous products: the representation of hillforts - often absent in the depictions of European barbarians in Roman films - albeit at the cost of being conceived not so much from the abundant archaeological documentation on the hillforts of the islands, but from the design of Tolkien's fantasy cities or the Dungeons \& Dragons series. At the same time, there is an interesting parallel between Barbarians and Britannia in the representation of the places where the legions camp: in both series the camps are located in the middle of forests and lack visibility of their surroundings, as if denoting an opposition between their open, inhabited space and the wildness of the territory.

This is a visual universe of indigenous unreality, megalithism, Bronze Age rock art, cavernous palace sets typical of the worlds explored by Flash Gordon, some emblematic Celtic jewels from the British Museum, promotional images directly inspired by cult films such as Trainspotting and, above all, the construction of a fantastic world from which the Britons enter and leave thanks to a consumption of hallucinogens that also harks back to the Pulp cinema of the 1960s. Faced with this world, the Roman opponent, General Aulus Plautius, opposes it with political cunning until he himself is trapped by the tempting option of magical power.

All this makes Britannia an intriguing audiovisual proposition, with a cultural genealogy that is based more on its cultural invention than its archaeological reality. 


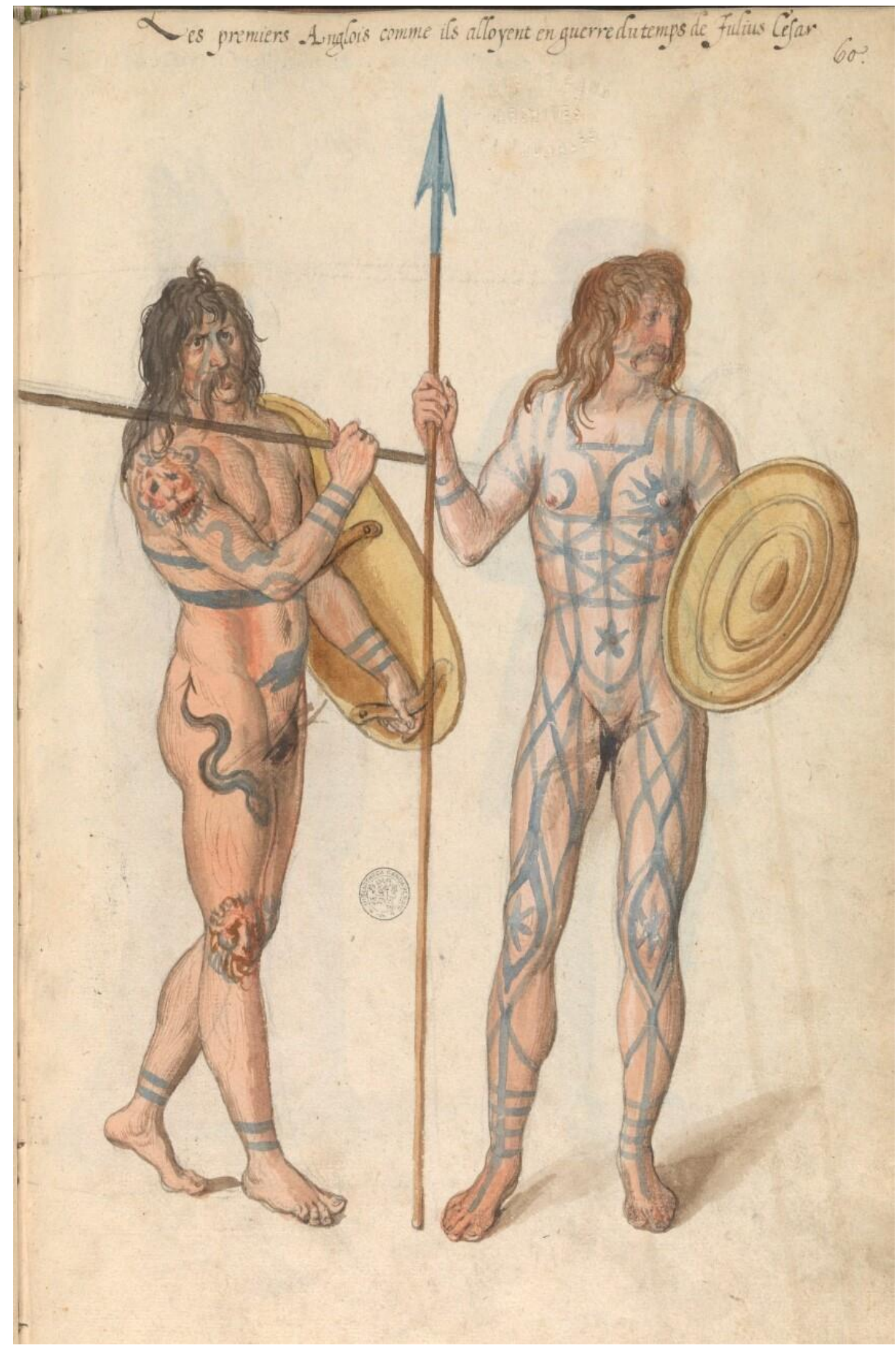

Figure 3. Perception of the first "English people" in times of the war against Julius Caesar, by Lucas de Heere (Ghent University Library CC BY-SA 4.0) 


\section{Conclusions}

The analysis of the series Barbarians and Britannia has allowed us to contrast two models of representation of the Iron Age in Europe and the British Isles. One of them seeks historical and archaeological rigor in the representation of indigenous people and Romans (Barbarians), while the second develops an audiovisual ethnography influenced by the western genre and contemporary movements such as Celtic raising, the counterculture of the 1960s or folk horror cinema (Britannia).

Beyond the audiovisual language and the different choices for the representation of the Iron Age peoples, the common element of both proposals is the focus on the indigenous factor, as opposed to the usual Romano-centric narratives that dominate the audiovisual world since the peplum genre, with some notorious exceptions.

This narrative style coincides with the current emphasis on post-colonial discourses, where indigenous agency takes on special importance within the study of Roman expansionism. This allows these two productions to be appropriately situated in their time, and also appeals to those in Academia who view these audiovisual narratives from a certain distance. Notoriously, the debates here presented could be seen in the case of video games with historical setting or background. Video games are an even more important vehicle to present narratives about the past and interact with a reconstruction of such a past in a completely renewed way (Mol et al. 2017; Politopoulos et al. 2019; Morgan 2019). This research on the topic is already going, and as we could envision, it should be intertwined with the analysis of the consumption of TV-on-demand.

However, analysing audiovisual products from a historical-archaeological perspective requires caution, as the TV narrative, although also based on scientific literature, has a very different purpose than the academic interest in the indigenous societies of the Iron Age.

\section{References}

Abarquero Moras, F.J., 2006. Simbolismo cenital en el mundo vacceo a propósito de un recipiente de cerámica de las eras de San Blas (Roa, Burgos). BSAA Arqueología 72-73: 183-209.

Beltrán Lloris, F., 2004. Nos celtis genitos et ex hiberis: Notes on collective identities in Celtiberia, in: Cruz Andreotti, G., Mora Serrano, B. (Eds.), Identidades étnicas, identidades políticas en el mundo prerromano bispano: Universidad de Málaga: 87-146.

GARCÍA SÁNCHEZ, J., 2009. El uso político de objetos arqueológicos: las estelas gigantes de Cantabria. Saldvie: Estudios de prehistoria y arqueología 9: 249-264

GONZALES, A., 1990. La Fresque et l'Imposture. Le péplum : un genre cinématographique qui se débat entre Histoire et Imaginaire. Collection de l'Institut des Sciences et Techniques de l'Antiquité 429: 133-160.

Houten, J. 2021. A nerd's-eye view on Die Barbarian. Online at https://latinnow.eu/2021/01/29/a-nerds-eye-view-on-die-barbaren-bilingualism-ingermania/ $19^{\text {th }}$ January 2021. Access $1^{\text {st }}$ February 2021.

Mol, A., Vandemeulebroucke, C., Boom, K., Politopoulos, A. (Eds.), 2017. The interactive past. Archaeology, heritage and videogames. Sidestone Press, Leiden. 
Morgan, C., 2019. Avatars, Monsters, and Machines: A Cyborg Archaeology. European Journal of Archaeology 22: 324-337. https://doi.org/10.1017/eaa.2019.22

Politopoulos, A., Mol, A., Boom, K.H.J., ArIese, C.E., 2019. "History Is Our

Playground": Action and Authenticity in Assassin's Creed: Odyssey. Advances in

Archaeological Practice 7: 317-323. https://doi.org/10.1017/aap.2019.30

Roymans, N., 1996. From the Sword to the Plough: Three Studies on the Earliest Romanisation of

Northern Gaul: Amsterdam University Press, Amsterdam.

SiCLIER, J., 1962. L'âge du péplum. Cahiers du cinéma 13: 26-38.

ZIZEK, S. 1997. The plague of fantasies. (El acoso de las fantasías. Siglo ventiuno editores.

2007 Spanish Edition). 
